\title{
HOUSING POLICY OF A BIG CITY: SOCIO-PSYCHOLOGICAL CONDITIONS AND REQUIREMENTS (RESEARCH ON THE EXAMPLE OF IVANO-FRANKIVSK)
}

\author{
Smadych I.P., PhD, Associate Professor, \\ Architectvan@gmail.com, ORCID: 0000-0001-7964-5730 \\ Institute of Architecture, Construction and Energy, IFNTUOG \\ 15, Karpatska street, Ivano-Frankivsk, 76019, Ukraine
}

\begin{abstract}
This article is devoted to the study of the topical problem of qualitative accounting of socio-psychological conditions of human life in residential architecture, namely in the policy of forming the urban environment. The task of this study can be realized by analyzing the regulatory framework, namely, strategies for the socio-economic and spatial development of cities in parts related to housing construction, housing and communal policy, general planning and territorial principles of city development. Systematization and comparison of this information made it possible to single out the factors influencing the formation of design solutions and development in the city. Another important link in this study is the systematization of factors influencing the solution of the problems of forming a living environment. The aim of this study is to characterize the impact of socio-psychological requirements for environmental comfort in the context of housing policy in large cities. In accordance with the purpose of the study, the following tasks were formed: to streamline the system of socio-psychological factors and methods of their accounting in substantiating the housing policy of urban space; to analyze the socio-economic and spatial development strategies of the city of Ivano-Frankivsk for the last 5 years and sectoral documents of the architectural and construction sector and housing policy; to highlight the factors that underlie the formation of housing policy in Ivano-Frankivsk, to develop recommendations for taking into account the psychological aspects of society in the formation of housing policy in cities.

The materials of this study are the aging of the socio-economic and spatial development of Ivano-Frankivsk for the last 5 years, as well as industry documents where the prospects for the development of the housing industry and housing policy are formed. The source base of the study to characterize the factors influencing the formation of the city's residential policy are scientific works on psychology, sociology, architectural sociology and public administration. The main research methods of this article are the method of factorial comparison. The methods of group comparison, and the graphical-analytical method of creating a structural model of factors and determining the place, as well as the role of socio-psychological factors in this model, were also used.
\end{abstract}

Keywords: city development strategy, city housing policy, socio-psychological aspects of a person, programs for the development of housing and communal services.

Introduction. In the period from 2010 in Ivano-Frankivsk, the pace of construction of residential real estate is actively growing, which is associated with increasing demand for housing [1]. Internal market competition and consumer tastes have increased the requirements for design solutions of residential buildings and complexes, spatial arrangement of residential areas, the quality of building systems and finishing materials. Also, in the pursuit of potential buyers, developers create the conditions for a developed system of social infrastructure, improvement of territories and providing storage conditions for cars in residential areas. The living space of apartments is also increasing, as a result, in the period from 2015, residential real estate experts distinguish in addition to the main 4 classes of housing, additional classes "comfort +" and "economy +" [2].

However, the improvement in living conditions caused by market mechanisms is only indirectly reflected the system of regulatory administration of local government. Another important problem in this area is only the assessment of economic trends in the real estate market in accordance with which the types and class of new buildings are formed. At the local government level, there is no social stratification of potential residents and it take into account not only the physical dimensions of comfort

Bulletin of Odessa State Academy of Civil Engineering and Architecture, 2020, no. 81, page 42-51 
(living space, creating quality engineering systems), but also socio-psychological requirements for housing comfort, which is a priority for sustainable development of any city.

Analysis of recent sources of research and publications. The need for housing is the primary link in the needs of each person. Many scholars agree that housing itself is a reflection of the many socio-psychological characteristics of each resident, his character, sense of comfort, mental and cultural peculiarities. The modern paradigm of humanization of architecture, puts man and his needs at the center of all processes taking place around. Accordingly, there is a growing scientific interest in interdisciplinary research, the purpose of which is to develop methods for assessing the impact of intangible aspects of human life in architecture.

Demographic, social, psychological features of human stay in housing and factors influencing the architectural and planning decision of the latter, are widely considered in the works of domestic authors: Bezsonova O.E., Durmanova V.Y., Zabruskova M.Y., Kartashova K.K., Kanaeva I.M., Kianenko K.V., Korol V.P., Lyzhina Y.M., Maistrenko K.S., Molchanova V.P., Ovsyannikova V.A., Orlova P.B., Platonova G.D., Ruzhzho V., Sadovsky S.A., Sidorova V.A., Smakula S.A., Smotrykivsky V.I. and others.

Questions about the architecture of housing, depending on human needs were studied in the works of domestic authors: Batalova Y.M., Grauzhis G.I., Pasternak A., Gul-Akhmedova A.I., Merzhanova B.M., Sikacheva A.V., Etenko V.P. etc., and foreign authors - Kemeni J. [3], Lepen B., Friedman A., Habraken N.D., Hertzberger G., Schneider T., Schramm G. [4], Fernandez R. [5] etc.

Some aspects of the manifestations of human psychology in housing policy are covered in works on applied psychology, sociology, personnel management Vilkovsky M.B., Levochkina A.M., Ushatsky S.A., Azgaldova G.G. [6], Gifford R. [7], Smolova L.

The purpose of this study is to characterize the impact of socio-psychological requirements for living comfort in the context of housing policy of large cities. In accordance with the purpose of the study, the following tasks were formed:

- to streamline the system of socio-psychological factors and methods of their consideration in the substantiation of housing policy of urban space;

- to analyze the socio-economic and spatial development strategies of the city of IvanoFrankivsk in the last 5 years and sectoral documents of the architectural and construction sphere and housing policy;

- to identify the factors that underlie the justification of housing policy in Ivano-Frankivsk;

- to develop recommendations, taking into account the psychological aspects of society in the formation of housing policy in cities.

Research materials. The materials of this study are the strategies of socio-economic and spatial development of Ivano-Frankivsk for the last 5 years [1], as well as sectoral documents, which highlight the prospects for the development of the housing industry and housing policy [8]. The source base of the study to characterize the factors that influence the formation of housing policy in the city are scientific papers on psychology, sociology, architectural sociology and public administration. The main methods of research of this article are the method of factor-by-factor comparison, which is used in the selection of factors influencing the housing policy of the city, as well as the graphoanalytical method and the method of group comparison.

Results of the research. Comfort, along with the safety of the human living environment are the priority functions of the housing policy of any locality. However, if the general characteristics of safety are scientifically sound and are represented by a number of quantitative indicators regulated by the regulatory framework, the category of "comfort" includes a large number of structural elements of the intangible aspect of human life. Taking into account our interest in sociopsychological conditions and requirements that affect the housing policy of Ukrainian cities, the primary task of this study is to substantiate the place and role of socio-psychological factors in shaping the housing policy of the urban environment. This study was conducted on the example of the residential sector of Ivano-Frankivsk, which is one of the 5 cities of Ukraine in terms of construction work performed. 
Systematization of factors influencing the housing policy of the city. Previous scientific studies have highlighted the markers that have an impact on the human environment [9]. In the system of "man-environment - activity" the social component is a priority for all levels of spatial development, because any influence of external and internal factors has a direct impact on the final change in living conditions. Together, these macro-factors shape a person's personality and affect all areas of his life. Thus, Khachatryants K.K., identifies the following social aspects of human life [10] (Fig. 1).

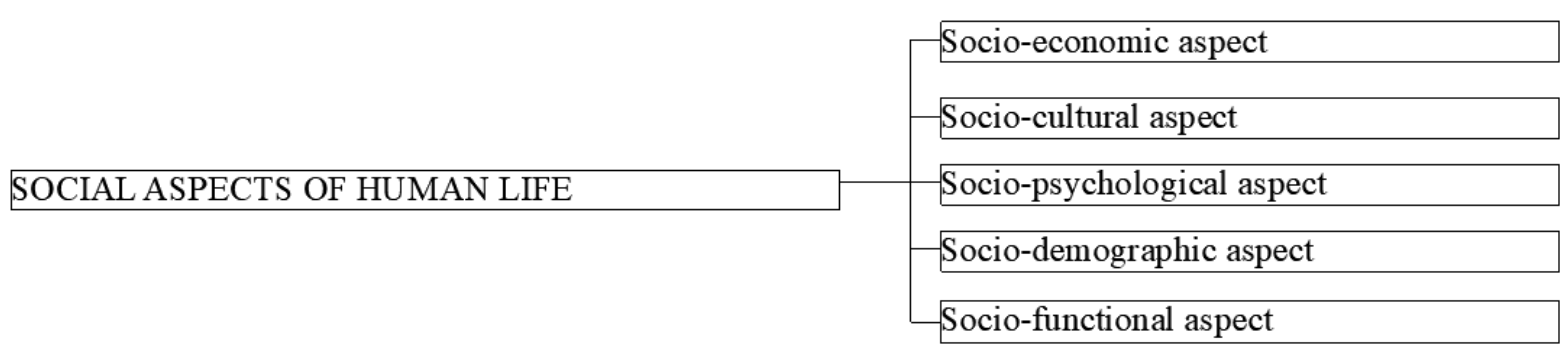

Fig. 1. Social aspects of human life (by K.K. Khachatryants)

The term "comfort" and "harmony" is identified with the term "human needs" as a balance between a sense of self-sufficiency and unity with society. In the architecture of the living environment, this term is interpreted as ensuring a comfortable stay of a person in space and providing many of the needs of his full life and leisure. M.J. Variy identifies the effects of space, time and energy on the psychological state of man in 4 main dimensions: physical (subject), vital (biological impact of the environment on the socio-psychological state of man), social (possibility of realization of human social life), spiritual dimension (spiritual human life). In our opinion, the influences of the main factors of socio-psychological life can be identified by the diversity of human life: namely, social, spiritual, political, professional, social, family, economic, personal [11]. In accordance with this, it can be argued that housing policy and the formation of an atmosphere of positive social relations in social groups at all levels is one of the components of a harmonious human life. In the architecture of the living environment, as a component that is crucial for the realization of individual needs, socio-psychological factors have the following stratification (Fig. 2):

- public communication (formation of a safe environment and communication with people);

- spiritual self-realization (providing human needs with religious, cultural, social, educational institutions, and a form of their functioning that would promote the development of personality);

- psycho-functional freedom (ensuring the variability of the regime and form of professional affiliation and functional activity);

- psycho-unconscious influence (the level of political and social activity of the population, the possibility of influencing the comfort of the living environment, racial, social and cultural features that have an impact on architecture).

In the theory of self-determination of R. Ryan and E. Desi, psychological well-being is identified with the satisfaction of basic psychological needs of man:

- the need for autonomy: the perception of their own behavior as congruent with their own system of values and desires;

- competencies: effective use of the environment to meet their own needs;

- positive relationships with others: the need for social communication with people.

For example, in his research to determine the level of comfort of residential buildings relative to the number of storeys, Roskovshenko A.Y. identifies such groups of socio-psychological factors as the visual environment, acoustic mode, observation of children, the area of engineering, communication and structural elements, as well as operating costs of the house. However, the factor of the area of engineering and structural elements does not belong to the basic needs of autonomy, because the priority is to meet the needs of the apartment interior quality, adjacent territory and the immediate surroundings.

Analysis of socio-economic and spatial development strategies of Ivano-Frankivsk. The formation of housing policy of a particular city refers to the level of complex architectural and urban

Bulletin of Odessa State Academy of Civil Engineering and Architecture, 2020, no. 81, page 42-51 
planning tasks. For this purpose, by analyzing the development strategies of Ivano-Frankivsk for the last 15 years, as well as related documentation, the priority factors of forming the system of planning and development of the city have been identified. The current "Strategy for the development of the city of Ivano-Frankivsk for the period up to 2028" is a program document consisting of 6 sections, which highlights the ways to implement the priority development goals of the city of Ivano-Frankivsk:

A. City of investment support and business development.

B. A city of energy efficient and environmentally friendly infrastructure.

C. The city of open government and modern governance.

D. The city of quality education, medicine, diverse cultural environment.

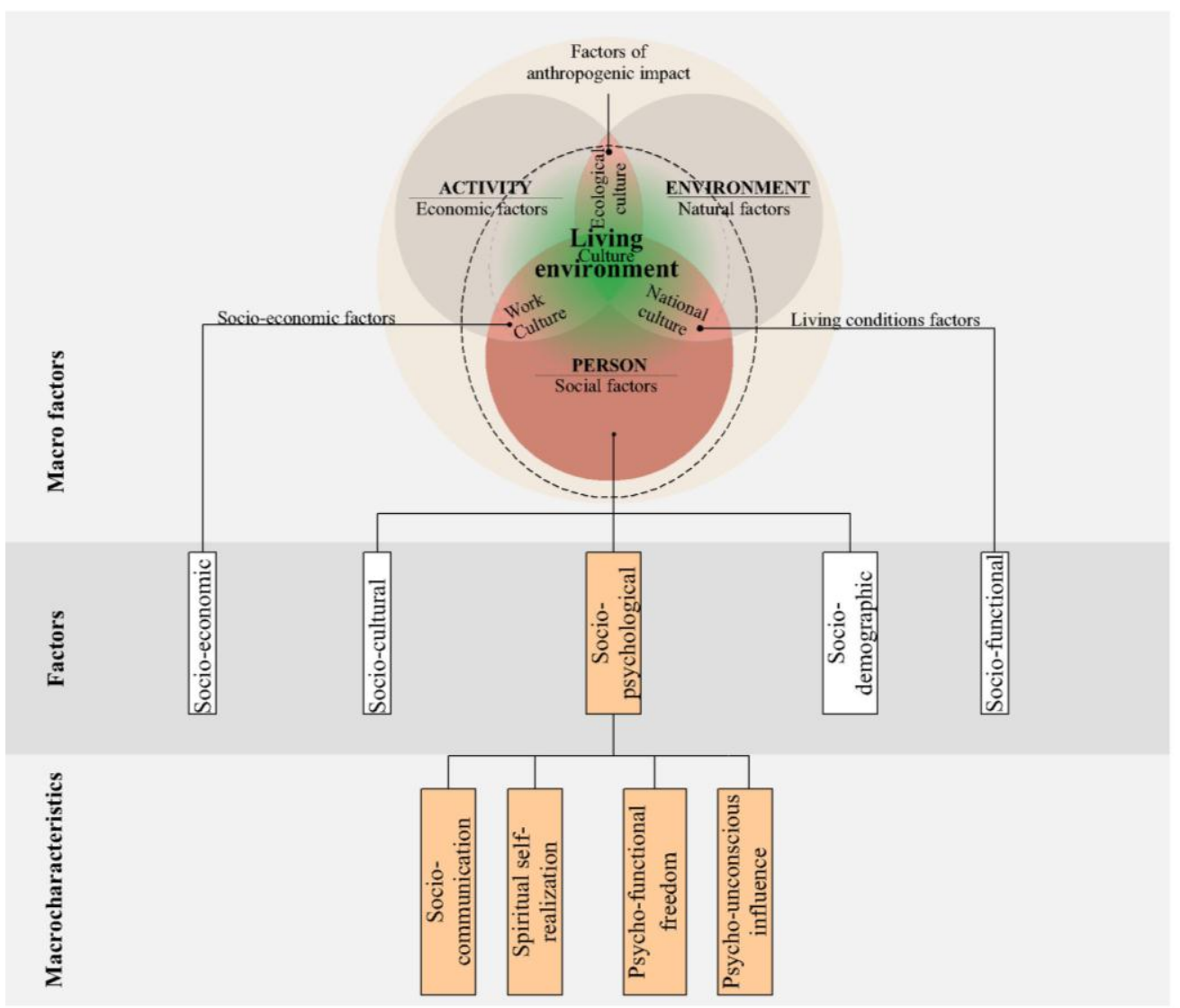

Fig. 2. General model of socio-psychological factors that affect the living environment of man (author's development)

For the period up to 2017 , the volume of construction work performed amounted to UAH 1037.8 million, which is $68.7 \%$ of the total regional volume [1]. The growth of the construction products index was $102.9 \%$. These indicators show the high intensity of the construction sector in Ivano-Frankivsk. The main share of construction work performed is $85.4 \%$ of the residential buildings sector (Fig. 3). In the context of this work, the study conducted by the analytical center "CEDOS" in the framework of the "Initiative for the development of analytical centers in Ukraine" is quite meaningful. The monitoring of statistical data, together with sociological research, is based on housing policy from the standpoint of social change [12].

In the period from 2018-2020, the pace of construction in Ivano-Frankivsk and the region along with Lviv actually doubled. 145\% increase in 2018. The main share (almost $80 \%$ ) of housing construction is the main type of commissioning (Fig. 3) However, these rates of housing construction leave their mark on the functioning of transport systems and social infrastructure, which will eventually complicate reforming the most stable components of the city, the road network, the compositional integrity of the historic core, etc. This study demonstrates the need to take into account the sociopsychological requirements of human life in the housing policy of the city. Here are some examples. 
As of 2019, new construction, reconstruction and technical re-equipment accounted for $85.5 \%$ of the total volume of construction work performed, capital and current repairs amounted to $9.5 \%$ and $5 \%$, respectively [1]. By analyzing the documentation, which reflects the development strategy of Ivano-Frankivsk, a number of factors influencing the construction sector and housing policy of the city are identified (Table 1).

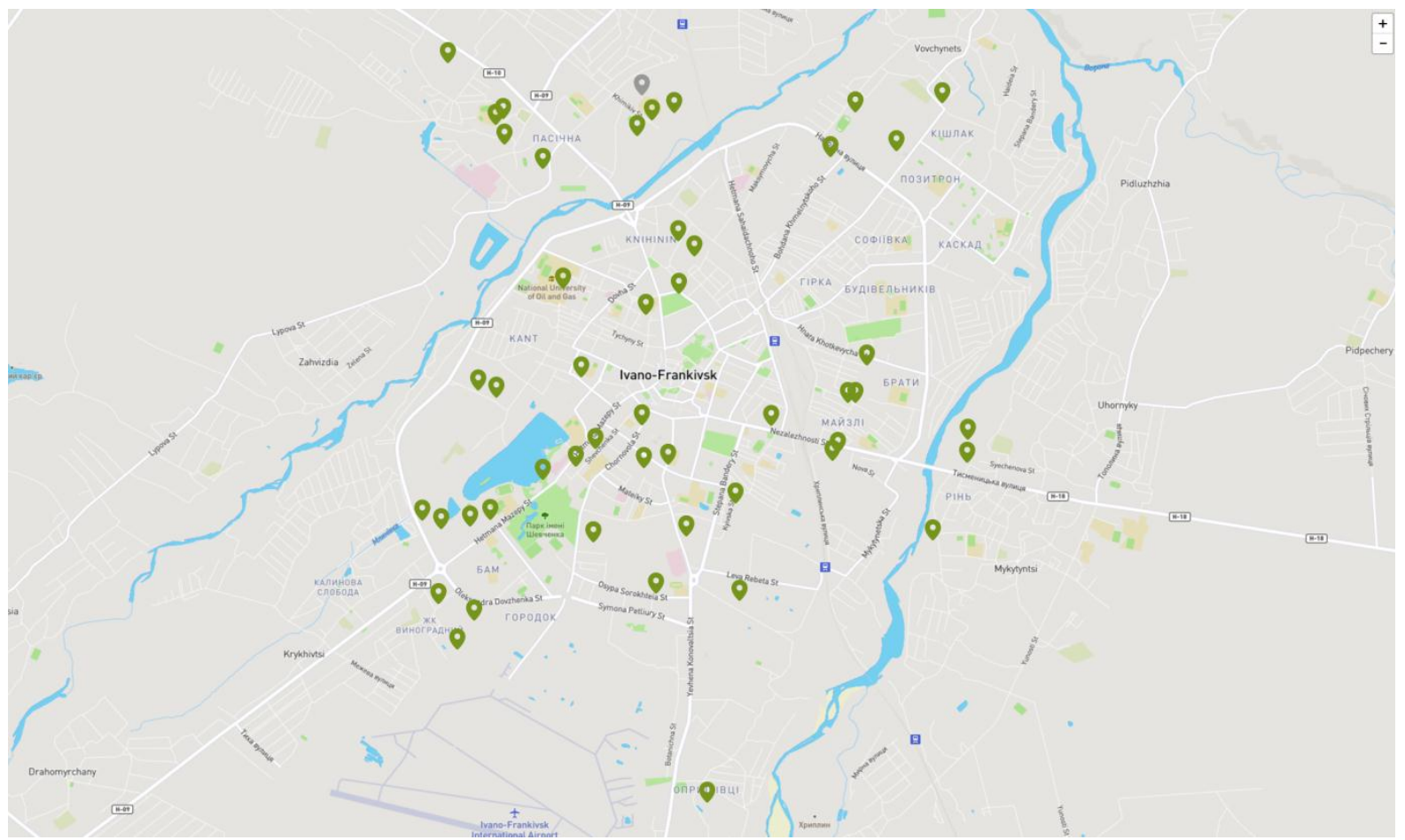

Fig. 3. Interactive map of new buildings in Ivano-Frankivsk as of 06.2020 [13]

Table 1 - Factors influencing the housing policy of Ivano-Frankivsk

\begin{tabular}{|c|c|c|}
\hline $\begin{array}{c}\text { Strategic goals of } \\
\text { Ivano-Frankivsk city } \\
\text { development }\end{array}$ & $\begin{array}{l}\text { Factors that have a direct impact on the } \\
\text { housing policy of the city }\end{array}$ & Category of factors \\
\hline \multicolumn{3}{|c|}{ Ivano-Frankivsk city development strategy for the period up to 2028} \\
\hline $\begin{array}{l}\text { A. City of investment } \\
\text { support and business } \\
\text { development }\end{array}$ & Missing & Missing \\
\hline \multirow{6}{*}{$\begin{array}{l}\text { B. A city of energy } \\
\text { efficient and } \\
\text { environmentally } \\
\text { friendly infrastructure }\end{array}$} & $\begin{array}{l}\text { The need for the development of green, } \\
\text { recreational areas in the city }\end{array}$ & socio-functional \\
\hline & preservation of valuable city buildings & socio-cultural \\
\hline & $\begin{array}{l}\text { public interest in participating in the } \\
\text { development of architectural and urban } \\
\text { planning documentation (city master plan) }\end{array}$ & socio-psychological \\
\hline & $\begin{array}{l}\text { lack of an effective policy of energy audit and } \\
\text { energy management of the housing stock of } \\
\text { the USSR period }\end{array}$ & socio-economic \\
\hline & $\begin{array}{l}\text { insufficient provision of public transport } \\
\text { network }\end{array}$ & socio-functional \\
\hline & $\begin{array}{l}\text { high prices for utility bills, which form the } \\
\text { need for the use of alternative energy sources }\end{array}$ & socio-economic \\
\hline
\end{tabular}


Continuation of Table 1

\begin{tabular}{|c|c|c|}
\hline & $\begin{array}{l}\text { public interest in the formation of } \\
\text { condominiums }\end{array}$ & socio-functional \\
\hline & $\begin{array}{l}\text { aggravation of ecological problems of the } \\
\text { city. }\end{array}$ & ecological culture \\
\hline $\begin{array}{l}\text { C. The city of open } \\
\text { government and } \\
\text { modern governance }\end{array}$ & increasing social interest in city life & socio-cultural \\
\hline $\begin{array}{l}\text { D. The city of quality } \\
\text { education, medicine, } \\
\text { diverse cultural } \\
\text { environment }\end{array}$ & $\begin{array}{l}\text { the need for modernization and development } \\
\text { of all areas of social security with appropriate } \\
\text { infrastructure development }\end{array}$ & socio-functional \\
\hline \multicolumn{3}{|c|}{$\begin{array}{c}\text { Regulations on the Department of Housing, Communal Policy and Public Works } \\
\text { Ivano-Frankivsk City Council }\end{array}$} \\
\hline \multicolumn{2}{|c|}{$\begin{array}{l}\text { the need for reform and development of housing and communal } \\
\text { services, construction, reconstruction, current and major repairs of } \\
\text { housing and facilities of the city }\end{array}$} & socio-functional \\
\hline \multicolumn{2}{|c|}{$\begin{array}{l}\text { social need to improve the technical condition of residential buildings } \\
\text { in the city }\end{array}$} & socio-functional \\
\hline \multicolumn{2}{|c|}{ reduction of energy consumption of residential buildings } & socio-economic \\
\hline \multicolumn{2}{|c|}{$\begin{array}{l}\text { increasing the social interest of citizens in the management of housing } \\
\text { (creation of a system of condominiums) }\end{array}$} & socio-functional \\
\hline \multicolumn{2}{|c|}{$\begin{array}{l}\text { compliance with regulatory requirements for construction and } \\
\text { management of land }\end{array}$} & socio-functional \\
\hline \multicolumn{2}{|c|}{$\begin{array}{l}\text { social providing of housing for employees of individual enterprises and } \\
\text { institutions }\end{array}$} & socio-psychological \\
\hline \multicolumn{3}{|c|}{$\begin{array}{c}\text { Ivano-Frankivsk Housing and Communal Services Development Program } \\
\text { for 2018-2022 }\end{array}$} \\
\hline \multicolumn{2}{|c|}{$\begin{array}{l}\text { time requirements for the modernization of facade solutions of } \\
\text { residential buildings }\end{array}$} & $\begin{array}{l}\text { socio-functional, } \\
\text { socio-economic }\end{array}$ \\
\hline \multicolumn{2}{|c|}{$\begin{array}{l}\text { socio-economic factors to improve the performance of buildings (by } \\
\text { increasing energy efficiency) }\end{array}$} & socio-economic \\
\hline \multicolumn{2}{|c|}{$\begin{array}{l}\text { social factors of constant modernization of recreational and } \\
\text { recreational areas of the city }\end{array}$} & socio-functional \\
\hline \multicolumn{2}{|c|}{$\begin{array}{l}\text { increasing attention to the environmental problems of the city and the } \\
\text { region }\end{array}$} & ecological culture \\
\hline \multicolumn{2}{|c|}{$\begin{array}{l}\text { increasing needs of quality of life in surrounding space (organization } \\
\text { of street lighting refining and improvement of surrounding areas) }\end{array}$} & $\begin{array}{l}\text { socio-functional, } \\
\text { socio-economic }\end{array}$ \\
\hline \multicolumn{3}{|c|}{ Explanatory note to the master plan of the city as of 2019} \\
\hline \multicolumn{2}{|c|}{$\begin{array}{l}\text { positive demographic growth of the city population as a result of } \\
\text { demand for new housing }\end{array}$} & socio-demographic \\
\hline \multicolumn{2}{|c|}{$\begin{array}{l}\text { problems of increased building density in the central part of the city, as } \\
\text { a consequence of the reorientation of housing policy to low-rise } \\
\text { manor-type buildings }\end{array}$} & socio-functional \\
\hline \multicolumn{2}{|c|}{$\begin{array}{l}\text { formation of new types of apartments in connection with the decline in } \\
\text { demand for apartments "economy" and "comfort" class }\end{array}$} & socio-economic \\
\hline
\end{tabular}


Analysis of the factors underlying the development of housing policy in Ivano-Frankivsk, it can be argued that the vector of improving socio-economic indicators is a priority in the construction and housing and communal services. Human resources are a priori considered in the context of human resources. This housing policy of the city does not actually take into account the socio-psychological conditions (factors) of life, and the only effective regulator of the mood of the inhabitants of these areas are the economic criteria of purchasing power, population level and so on.

Identification of priority factors in the formation of housing policy in Ivano-Frankivsk. As noted above, the socio-psychological and generally intangible component of human life should be considered from the standpoint of social, spiritual, political, professional, social, family, economic, personal components of his life. The general indicator of the "happiness index", which partially assesses individual social, professional, family components does not allow to identify the requirements related to the housing policy of the city. Foreign experience shows that the most effective method of analysis and assessment of socio-psychological living conditions and their implementation in the development of housing and communal and construction of the city is a system of monitoring the conditions of housing development through sociological surveys and housing management (ACMH), as well as a system of transparent public discussions taking into account the wishes of residents. Also an important part of the analysis and assessment of the development of the construction sector of the city is an expert multi-criteria analysis, which forms a slice of the prospects for the development of the living environment.

The dynamics of changes in employment in the world during the coronary virus pandemic in 2020 shows the transition to remote work of certain categories of workers. Ivano-Frankivsk, along with Ukrainian cities, is one of the 10 cities with the largest development of the IT sector in Ukraine. The requirements of psycho-functional freedom indicate the need for the formation of new types of buildings, where social infrastructure and offices (so-called multifunctional housing complexes) are concentrated next to residential buildings. Another example of changing sociopsychological requirements in architecture is the increase in competence requirements (the desire to realize the full range of needs and functions in the immediate vicinity of housing). As a result, there is a need to reform the city's housing policy in the field of social infrastructure. For example, increase the ratio of the social infrastructure fund to the residential and commercial fund, and architectural solutions of residential buildings (introduce the share of the social fund in the design decisions of residential buildings; the formation of green exploited gardens, etc.). Such nonstandard solutions, which are the norm in the world practice of housing construction, will improve the living conditions of its residents and the investment attractiveness of the city as a whole.

Recommendations considering socio-psychological factors in the housing policy of IvanoFrankivsk. In accordance with the analyzed information, recommendations are formed to take into account the socio-psychological conditions and requirements in the housing policy of the city:

- monitoring and evaluation of indicators of the level of comfort of the living environment, as an objective basis for prognostic models and problems of development of individual settlements in Ivano-Frankivsk;

- taking into account the requirements of psycho-functional freedom in the process of architectural design of residential buildings, namely zoning and functional purpose of individual premises, stratification of housing and commercial stock, including the share of social infrastructure;

- taking into account the requirements of social communication, by increasing the areas of communication in residential buildings and inter-building spaces and regulating the location and capacity of the new housing stock.

\section{Conclusions:}

1. The functioning of any spatial system is influenced by a number of factors, taking into account which is a condition for sustainable development of space and harmonious life of people. In a special way the requirements of a comfortable life in the living environment are implemented. The study found that a special role for the general criteria of comfort and sustainable development have socio-psychological factors that have a decisive influence on human life. 
2. Characteristics of spatial development strategies of Ivano-Frankivsk, shows the complexity of the tasks that underlie it and a large number of factors that affect the housing policy of the city through the diversity of human habitat.

3. Analyzing the socio-economic and spatial development strategies of Ivano-Frankivsk in the period from 2015-2020, it is determined that human resources, a priori, are considered in the context of labor resources and socio-economic indicators that underlie the development of housing policy.

4. In accordance with this, recommendations have been developed to take into account sociopsychological factors in the housing policy of cities, namely: monitoring and evaluation of indicators of the level of comfort of the living environment; taking into account the requirements of psycho-functional freedom in the process of architectural design of residential buildings; taking into account the requirements of social communication, by increasing the areas of communication in residential buildings.

\section{References}

[1] Ivano-frankivska miska rada. Stratehiia rozvytku mista Ivano-Frankivska na period do 2028 roku. [Online]. Available: http://www.mvk.if.ua/uploads/files/46819.pdf.

[2] Yedynyi klasyfikator zhytlovykh budynkiv zalezhno vid yakosti zhytla ta naiavnoho inzhenernoho obladnannia, zatverdzhenyi Nakazom Derzhbudu Ukrainy vid 30.09.1998 no. 215. K: Minrehionbud Ukrainy. 2016.

[3] J. Kemeny, J. Kersloot and P. Thalmann, "Non-profit Housing Influencing, Leading and Dominating the Unitary Rental Market: Three Case Studies", Housing Studies, vol. 20, no. 6, pp. 855-872, 2005.

[4] H. Schramm, Low Rise Density. Horizontale Verdichtungsformen im Wohnbau. Springer Wien New York. 2005.

[5] R. Fernandez and M.B. Aalbers, "Financialization and housing: Between globalization and Varieties of Capitalism", Competition \& Change, vol. 20, no. 2, pp. 71-88, 2016.

[6] H.H. Azghaldov, Kvalymetryia zhyzny: monohrafyia. Moskva: Vserossyiskyi tsentr urovnia zhyzny, 2006.

[7] Robert Gifford, "The Consequences of Living in High-Rise Buildings", Architectural Science Review, vol. 50, no. 1, pp. 35-38, 2007.

[8] Informatsiia pro vykonannia Prohramy ekonomichnoho i sotsialnoho rozvytku IvanoFrankivskoi miskoi obiednanoi terytorialnoi hromady za 2019 rik. [Online]. Available: http://www.mvk.if.ua/sektors/52534.

[9] I.P. Smadych, "Klasyfikatsiia sotsialnykh chynnykiv: kharakterystyky, pokaznyky ta kryterii otsinky yikh vplyvu na arkhitekturu zhytlovoho seredovyshcha", Molodyi vchenyi, no. 1 (77), 2020. https://doi.org/10.32839/2304-5809/2020-1-77-14.

[10] K.K. Khachatriants, Arkhitektura i liudski vzaiemyny. Sotsialno-psykholohichni osnovy seredovyshchnoho tvorennia. Tallin: EOOP SRSR, TPED im. E. Vilde, 1985.

[11] M.I. Varii, Enerhetychna kontseptsiia psykhiky ta psykholohichnoho. K. Tsentr uchbovoi literatury, 2019.

[12] Derzhavna zhytlova polityka v Ukraini. Suchasnyi stan ta perspektyvy rozvytku. K.: Analitychnyi tsentr CEDOS, 2019.

[13] Interaktyvna mapa novobudov Ukrainy. [Online]. Available: https://azuz.org.ua/lvivinteractive-map. 


\title{
ЖИТЛОВА ПОЛІТИКА ВЕЛИКОГО МІСТА: СОЦІО-ПСИХОЛОГІЧНІ УМОВИ ТА ВИМОГИ ДО ФОРМУВАННЯ (ДОСЛІДЖЕННЯ НА ПРИКЛАДІ М. ІВАНО-ФРАНКІВСЬКА)
}

\author{
Смадич І.П., к.арх. доцент, \\ Architectvan@gmail.com, ORCID: 0000-0001-7964-5730 \\ Iнститут архітектури, будівниитва та енергетики ІФНТУНГ \\ вул. Карпатська, 15, м. Івано-Франківськ, 76019, Україна
}

\begin{abstract}
Анотація. Дана стаття присвячена дослідженню актуальної проблеми якісного врахування соціо-психологічних умов життя людини в житловій архітектурі, а саме в політиці формування міського середовища. Завдання представленої публікації реалізуються шляхом аналізу нормативно-правової бази, а саме стратегій соціально-економічного i просторового розвитку міст в частинах, що стосуються житлового будівництва, житловокомунальної політики, генерального планування і територіальних принципів розвитку міста. Систематизація і порівняння даної інформації дозволило виділити чинники, що впливають на формування проєктних рішень i забудови в місті. Іншою важливою ланкою даного дослідження $є$ систематизація факторів впливу на вирішення завдань формування житлового середовища. Метою даного дослідження є характеристика впливу соціо-психологічних вимог комфортності середовища в контексті житлової політики великих міст. Відповідно до мети дослідження сформовані наступні завдання: впорядкувати систему соціо-психологічних факторів і методів їх врахування в обгрунтуванні житлової політики міського простору; проаналізувати соціо-економічні та просторові стратегії розвитку міста Івано-Франківська за останні 5 років, а також галузеві документи архітектурно-будівельної сфери та житлової політики; виділити фактори, які покладені в основу формування житлової політики м. ІваноФранківська, розробити рекомендації врахування психологічних аспектів соціуму при формуванні житлової політики міст.

Матеріалами даного дослідження є стратегії соціально-економічного і просторового розвитку м. Івано-Франківська за останні 5 років, а також галузеві документи, де сформовані перспективи розвитку архітектурно-будівельної галузі та житлової політики. Джерелом дослідження для характеристики даних факторів, що впливають на формування житлової політики міста $\epsilon$ наукові праці 3 психології, соціології, архітектурної соціології та державного управління. Основними методами дослідження даної статті $\epsilon$ метод пофакторного порівняння. Також використані методи групового порівняння, i графоаналітичний метод створення структурної моделі.
\end{abstract}

Ключові слова: стратегія розвитку міста, житлова політика міста, соціо-психологічні аспекти людини, програми розвитку житлово-комунального господарства.

\section{ЖИЛИЩНАЯ ПОЛИТИКА БОЛЬШОГО ГОРОДА: СОЦИО-ПСИХОЛОГИЧЕСКИЕ УСЛОВИЯ И ТРЕБОВАНИЯ (ИССЛЕДОВАНИЕ НА ПРИМЕРЕ Г. ИВАНО-ФРАНКОВСК)}

Смадич И.П., к.арх. доцент, Architectvan@gmail.com, ORCID: 0000-0001-7964-5730 Институт архитектуры, строительства и энергетики, ІФНТУНГ ул. Карпатская, 15, г. Ивано-Франковск, 76019, Украина

\begin{abstract}
Аннотация. Данная статья посвящена исследованию актуальной проблемы качественного учета социо-психологических условий жизни человека в жилой архитектуре, а именно в политике формирования городской среды. Задачи представленного исследования реализуются путем анализа нормативно-правовой базы, а именно стратегий социальноэкономического и пространственного развития городов в частях, касающихся жилищного
\end{abstract}


строительства, жилищно-коммунальной политики, генерального планирования и территориальных принципов развития города. Систематизация и сравнение данной информации позволило выделить факторы, влияющие на формирование проектных решений и застройки в городе. Другим важным звеном данного исследования является систематизация факторов влияния на решение задач формирования жилой среды. Целью данного исследования является характеристика влияния социо-психологических требований комфортности среды в контексте жилищной политики крупных городов. В соответствии с целью исследования сформированы следующие задачи: упорядочить систему социопсихологических факторов и методов их учета в обосновании жилищной политики городского пространства; проанализировать социо-экономические и пространственные стратегии развития города Ивано-Франковска за последние 5 лет, а также отраслевые документы архитектурно-строительной сферы и жилищной политики; выделить факторы, которые положены в основание формирования жилищной политики г. Ивано-Франковска, разработать рекомендации учета психологических аспектов социума при формировании жилищной политики городов.

Материалами данного исследования являются стратегии социально-экономического и пространственного развития г. Ивано-Франковска за последние 5 лет, а также отраслевые документы, где сформированы перспективы развития жилой индустрии и жилищной политики. Источником исследования для характеристики факторов, влияющих на формирование жилой политики города являются научные труды по психологии, социологии, архитектурной социологии и государственного управления. Основными методами исследования данной статьи есть метод пофакторного сравнения. Также использованы методы группового сравнения, и графо-аналитический метод создания структурной модели факторов и определение места, а также роли социо-психологических факторов в этой модели.

Ключевые слова: стратегия развития города, жилищная политика города, социопсихологические аспекты человека, программы развития жилищно-коммунального хозяйства.

Стаття надійшла до редакції 14.09.2020 